\title{
Toxicological and Biological Assessment of the Effect of Sapropel of the Prybych Lake during Cutaneous Application in Rats
}

\author{
Oksana Strus ${ }^{1}$, Konstantin Babov ${ }^{2}$, Sergey Gushcha ${ }^{2 \star}$, Nataliia Polovko ${ }^{3}$, Boris Nasibullin ${ }^{4}$, Tetiana Polshchakova ${ }^{2}$ \\ ${ }^{1}$ Department of Drug Technology and Biopharmaceutics, Danylo Halytsky Lviv National Medical University, Lviv, Ukraine; \\ ${ }^{2}$ Department of Medical Rehabilitation, State Institution "Ukrainian Research Institute of Medical Rehabilitation Therapy of \\ Ministry of Health of Ukraine," Odessa, Ukraine; ${ }^{3}$ Department of Drug Technology, National University of Pharmacy, Kharkiv, \\ Ukraine; ${ }^{4}$ Department of Basic Research, State Institution "Ukrainian Research Institute of Medical Rehabilitation Therapy of \\ Ministry of Health of Ukraine," Odessa, Ukraine
}

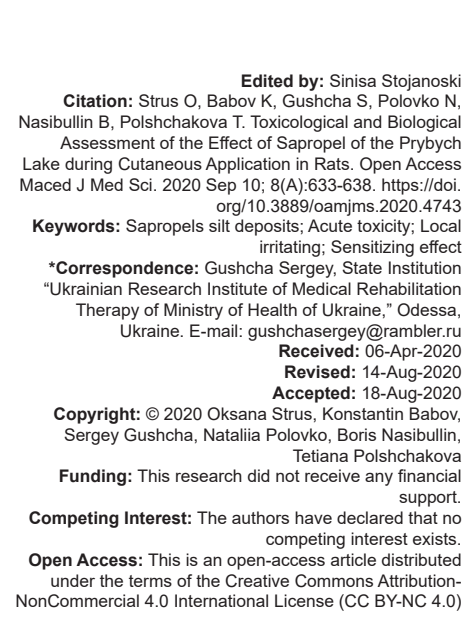

\section{Introduction}

Peloid therapy is one of the oldest methods of using natural healing resources for medicinal purposes. Even though sapropelic peloids (sapropels) contain compounds with high biological activity, their extensive therapeutic use was constrained by the difficulties of extraction and procurement, as well as the lack of information about the therapeutic action of this type of peloids [1], [2]. Experimental studies have established that during treatment with sapropels, lymph and blood circulation improves, the vascular wall strengthens, and the functions of the autonomic nervous system are stimulated [3]. The following authors showed that sapropels stimulate metabolic processes in tissues, increasing oxygen metabolism, contribute to the activation of the body's immune responses, have antibacterial and detoxifying effects, and enrich the body with vital macro- and microelements, vitamins, and amino acids [4], [5], [6]. The above-obtained data on the medicinal properties of sapropels provide a basis for the development of a new direction in pharmacy and pharmacology associated with the creation of new drugs based on peat and sapropel [7], [8], [9].

To determine the prospects for the further use of sapropels and their products in balneology and cosmetology as an active pharmaceutical ingredient in the creation of drugs and veterinary drugs it is mandatory to assess the degree of toxicity. In toxicological studies, the nature and severity of their possible damaging effects on the body of experimental animals are established, which organs and tissues are most sensitive to potential biologically active substances, and what should be paid attention to during clinical trials [10], [11], [12]. 


\section{Objectives}

The purpose of this work was to determine the effect of the sapropel from the Prybych Lake on the:

1. Functional state of the central nervous system (CNS) and the autonomic reactions of the body

2. Structural and functional state of the stomach, heart, liver, and kidneys, and

3. To determine the local irritating and sensitizing effects of sapropaste when used externally in white rats to justify the prospects for their use in balneology, medicine, and for the development of new drugs.

\section{Materials and Methods}

Object of study: Sapropel of Lake Prybych of the group of Shatsky lakes of the Volyn region of Ukraine, pasta from sapropel (sapropaste), white rats.

The sapropels of the Prybych Lake are algal mules, uniform in composition, dark green in color, and are low-ash organic sapropel. The concentration of organic substances is $29 \%$. From the balneological point of view, the essential characteristics of peloids are a large mass fraction of moisture, stickiness, and bias stress, which are quite high in the sapropels of the Prybych Lake. The mass fraction of moisture is more than $96 \%$, and the bias voltage is $610.96 \mathrm{~Pa}$ (Pascal). That is, these sapropels in terms of their basic physicochemical parameters correspond to the requirements for sapropelic peloids during the release of medical procedures [13].

The mud solution of sapropel was obtained by mixing the sapropel of the Prybych deposit with distilled water in a ratio of $1-3$ (or $100 \mathrm{~g}$ of sapropel to $300 \mathrm{ml}$ of distilled water).

Sapropelic paste(sapropaste) is ahomogeneous pasty mass of dark brown color, with a moisture content of $83 \%$, made from dehydrated sapropel by cavitation, which results in a high content of biologically active substances, high plasticity, and adhesive properties. This feature makes sapropaste convenient when used in cosmetology in its pure form and mixed with other active elements (in the form of wraps, masks, etc.) [14].

Experimental studies were carried out on 50 clinically healthy male rats (Wistar strain) aged 6-8 months, weighing 180-210, in compliance with the requirements for the humane treatment of experimental animals regulated by relevant documents [15], [16]. During the experiment, the animals were in the vivarium at a temperature of $19-24^{\circ} \mathrm{C}$, the humidity was not more than $50 \%$, natural day-night light mode, in plastic cages, on a balanced diet [16]. The animals had free access to water. They were allowed to eat only $4 \mathrm{~h}$ after applying sapropels.
The toxicological and biological assessment of the effect of the sapropel of the Prybych Lake for external use in rats was carried out in two stages.

At the first stage of the study, we evaluated the effect of the sapropel from the Prybych Lake on the functional state of the CNS, the autonomic reactions of the body, and the structural and functional changes in the internal organs in the experimental-biological clinic (vivarium) of the State Institution "Ukrainian Research Institute of Medical Rehabilitation Therapy of Ministry of Health of Ukraine," Odessa, (Protocol No. 48 dated January 8, 2019, of the Bioethics Commission).

At this stage of the study, rats were placed in individual canisters with openings for breathing and ventilation. After that, the tail of the animal, $2 / 3$ of the length, is immersed for $2 \mathrm{~h}$ in a container with sapropel. The temperature was maintained at a constant level and corresponded to the body temperature of the animal $\left(39-40^{\circ} \mathrm{C}\right)$. The course consisted of six treatments every other day. The experimental animals were divided into two groups per 10 animals of each $(n=10)$ : The $1^{\text {st }}$ group - intact rats (control) and $2^{\text {nd }}$ - the rats, which underwent procedures with sapropel solution.

The functional state of the CNS and emotional activity (EA) was studied according to the generally accepted "open field" technique [17]. In our studies, using this test, we examined the state of CNS activity as estimated by changes in orientation-research behavior, motor activity, and the level of the emotional state of animals. In the study of behavior, we recorded the number of exits to the center, crossed squares, uprights, cleansing (grooming), stops, boluses, and urinations. When processing the results took into account, the following total indicators:

1. Movement activity is the sum of the number of exits to the center

2. The quantity

3. Duration of animal stops.

Approximate research behavior - the sum of the amount of crossed squares, uprights, and peering into minks. EA is the sum of the number and length of grooming (cleansing), urination, and bowel movements (boluses). For each individual rat, the duration of the "open field" test was $6 \mathrm{~min}$. The obtained indicators were compared with the corresponding indicators of the $1^{\text {st }}$ group of animals (intact).

At the end of the course, the animals were taken out of the experiment by decapitation under ether anesthesia. During the autopsy of experimental rats, a visual macroscopic assessment of the state of the internal organs of animals was carried out. Two pieces of liver, heart, stomach, and kidneys with a volume of $1 \mathrm{sm}^{3}$ were removed from rats.

The first piece was fixed for $24 \mathrm{~h}$ in $4 \%$ solution of paraformaldehyde, passed through increasing concentrations of alcohol, and poured into celloidin. Histological sections 7-9 $\mu \mathrm{m}$ thick were made from the 
obtained blocks, which were stained with hematoxylineosin according to the generally accepted method Van Gieson [18]. Microscopic studies of the structural changes in the stomach, heart, liver, and kidneys were performed on the preparations obtained.

The second piece was frozen with dry carbon dioxide $\left(-70^{\circ} \mathrm{C}\right)$, histochemical reactions were carried out on the prepared cryostat sections to determine the activity of succinate dehydrogenase and lactate dehydrogenase (LDH) according to the Lojda et al. prescription [18]. Enzyme activity was evaluated in arbitrary units of optical density (conventional units). The state of the target organs of experimental animals was assessed by comparing it with the corresponding indices of intact animals. The methods used are given in the manuals and approved by the Ministry of Health of Ukraine, experimental studies were carried out following legal documents [19].

The second stage was the study of acute toxicity, skin irritating, and sensitizing effects of sapropaste when applied externally. The study was conducted in the vivarium of the Laboratory of Molecular Biology and Clinical Biochemistry of the Institute of Animal Biology of the National Academy of Agrarian Sciences, Lviv (Protocol No. 14 of February 12, 2019, of the Bioethics Commission). The acute toxicity of the sapropaste was studied with a 1 time application to the skin (20). Assessment of toxicity was carried out according to the classification by Stefanov [20]. The study of the local irritative and sensitizing effects of sapropaste was performed on the skin application model [21]. Rats were divided into three groups, 10 animals each.

I. Intact (control) comparison group

II. A research group of rats, on which was used 1 time cutaneous application of sapropaste at the rate of $2810 \mathrm{mg} / \mathrm{kg}$

III. A research group of animals, on which was applied externally to the application of sapropaste to study the local irritating and sensitizing effects.

Test samples of sapropaste were applied to animals of Group II on a pre-clipped area of the skin of the back, which amounted to at least $10 \%$ of the total surface area of the animal. We recorded the effect of the drug on survival and calculated the median lethal dose $\left(L D_{50}\right)$, the main toxicological characteristic of the drug.

For experimental animals of Group III, sapropaste was applied to clipped skin areas $2 \mathrm{~cm} \times$ $2 \mathrm{~cm}$ in size (right and left sides), at a dose of $0.5 \mathrm{~g}$ for 4 weeks, 5 times a week, and once a day. The skin reaction of the right side was taken into account daily to identify the irritating effect of the drug. The local impact of the test drug on the skin was evaluated after the $10^{\text {th }}$ and $20^{\text {th }}$ applications visually according to the severity of erythema. The thickness of the skin folds of the right side was determined using a caliper.

Sensitization was also detected after the $10^{\text {th }}$ and $20^{\text {th }}$ applications by applying the final dose of the drug to the intact (left) side of the animal. Indicators that characterized the sensitizing effect of the studied objects, namely, the thickness of the skin fold and the degree of damage to the skin of the left side, were determined $24 \mathrm{~h}$ after the application of the final dose.

All data were processed using the statistical package Statistica 10.0 (Statsoft/Dell, Tulsa, OK, USA). The descriptive statistics of the data in tables include mean \pm standard error of the mean or mean \pm standard deviation. Significance was assessed using the one-way ANOVA followed by a t-test. Values were considered statistically significant when $p<0.05$.

\section{Results and Discussion}

At this stage of the study, we studied the effect of the sapropel solution of Prybych Lake on the functional state of the CNS and the autonomic reactions of rats. To comprehensively assess the levels of motor and behavioral activity of experimental animals and their response to the effects of chronic emotional stress, as well as the effects of damaging or toxic factors, studies of indicative psychophysiological parameters in the "open field" test were conducted [17], [22]. Features of the behavior of rats in the device "open field" are a prognostic criterion for the state of the CNS. Staying animals in a new environment lead to research motivation, accompanied by the formation of passive protective behavior. A characteristic manifestation of this condition is considered to be a vegetative reaction of animals in the form of defecation (boluses) and urination, as well as a change in the level of motor activity. Grooming (cosmetic behavior of animals) is a crucial characteristic of the behavior of rats in the device "open field." Rats spend a significant part of their time caring for their fur and skin, and in some cases, this process is longer than motor activity. Grooming was traditionally classified as a healthy behavior or a relaxed state. If the rats perform short-term grooming, or their number increased, and the duration reduced, this indicates that the animals are in a state of anxiety [23].

Data on the effect of the sapropel of Prybych Lake on the functional state of the CNS and the autonomic reactions of rats are given in Table 1.

Table 1: The effects of cutaneous use of sapropel on the indicators of the functional state of the central nervous system and the emotional activity of rats, $(M \pm$ standard error of the mean)

\begin{tabular}{llll}
\hline Indicators & Group 1 & Group 2 & $\mathrm{p}$ \\
\hline Number of exits to the center, $\mathrm{n}$ & $0.62 \pm 0.23$ & $0.57 \pm 0.03$ & 0.5 \\
Number of stops, $\mathrm{n}$ & $2,12 \pm 0,29$ & $2.62 \pm 0.05$ & 0.5 \\
Duration of stops, $\mathrm{s}$ & $181.75 \pm 7.92$ & $205.84 \pm 3.06$ & $0.05^{*}$ \\
Number of squares crossed, $\mathrm{n}$ & $40.31 \pm 4.54$ & $37.16 \pm 0.67$ & 0.5 \\
Number of uprights, $\mathrm{n}$ & $7.00 \pm 0.81$ & $5.59 \pm 0.07$ & 0.5 \\
Number of peeps in minks, $\mathrm{n}$ & $9.69 \pm 1.24$ & $9.52 \pm 0.08$ & 0.5 \\
Number of grooming, $\mathrm{n}$ & $1.94 \pm 0.23$ & $2.76 \pm 0.03$ & $0.01^{*}$ \\
Duration of grooming, $\mathrm{s}$ & $21.37 \pm 3.59$ & $36.31 \pm 0.15$ & $0.001^{*}$ \\
Number of defecation acts (boluses), $\mathrm{n}$ & $3.12 \pm 0.69$ & $2.21 \pm 0.05$ & 0.2 \\
Number of urination acts, $\mathrm{n}$ & $4.12 \pm 0.49$ & $5.16 \pm 0.06$ & $0.05^{*}$ \\
\hline 1. (Mean \pm SEM) - Mean and Standard error of mean; 2 " $^{*}$ - significant difference. &
\end{tabular}


The motor activity of animals practically does not change, as evidenced by the absence of statistically significant changes in the number of exits to the center of the open field device and the number of stops. An exception is a slight but notable increase in the duration of stops $(p<0.05)$. The approximate research behavior of animals that received a course of procedures with a sapropel also does not differ from the behavior of Group 1, as evidenced by the absence of significant changes in the number of crossed squares, the number of peeps in minks, and the number of vertical struts $(p>0.5)$.

The EA of animals under the influence of the use of sapropels characterized by an increase in the number of grooming acts $(p<0.01)$ and a more significant increase in the duration of grooming acts $(p<0.001)$. These data indicate that the animals feel calm and are in excellent emotional condition. Statistically significant increase in urination acts established $(p<0.05)$, which may be due to the stimulating effect of procedures with sapropel on the urinary function of the kidneys.

Thus, the external use of sapropels does not affect the functional activity of the CNS, has a slight calming effect on the emotional state of animals, and moderately stimulates some vegetative reactions.

Data on the structural and functional changes in target organs of rats and the degree of activity of enzymes of the basic reactions of energy formation mechanisms, primarily oxidation-reduction enzymes in the tissues of these organs, are presented in Table 2.

Table 2: The results of morphological studies of the internal organs of the II group of rats after cutaneous application of sapropel, ( $M \pm$ standard error of the mean)

\begin{tabular}{|c|c|}
\hline Organs & Structural and functional organization of organ tissues \\
\hline Stomach & $\begin{array}{l}\text { The submucous plate is dense, of a normal appearance, fibrous } \\
\text { fibers are not visually released. The glands of the mucosa have the } \\
\text { usual tubular structure; epithelial cells include a homogeneous weakly } \\
\text { basophilic cytoplasm and medium-sized nuclei; interstitial layers are } \\
\text { thin. Goblet cells of the excretory ducts was sharply enlarged, rich in } \\
\text { mucus }\end{array}$ \\
\hline Activity of SDH & $7.00 \pm 0.30 \mathrm{c}$. u. compared with the control $7.00 \pm 0.29 \mathrm{c}$. u. \\
\hline Activity of LDH & $7.00 \pm 0.41$ c. u. compared with the control $6.00 \pm 0.32 \mathrm{c}$. u. \\
\hline Liver & $\begin{array}{l}\text { The lobar structure preserved, the vessels in the lobules are full- } \\
\text { blooded, between the lobular layers are thin, dense. Hepatocytes are } \\
\text { collected in beams, most of them are of medium size, and the nuclei } \\
\text { are dark colored }\end{array}$ \\
\hline Activity of SDH & $6.00 \pm 0.45 \mathrm{c}$. u. compared with the control $7.00 \pm 0.29 \mathrm{c}$. u. \\
\hline Activity of LDH & $6.00 \pm 0.11 \mathrm{c}$. u. compared with the control $6.00 \pm 0.32 \mathrm{c}$. u. \\
\hline Heart & $\begin{array}{l}\text { Layered and bundle organization of the myocardium is preserved. } \\
\text { Nuclei of the cardiomyocytes are oval, juicy stained, transverse } \\
\text { hatching is determined }\end{array}$ \\
\hline Activity of SDH & $7.00 \pm 0.24 \mathrm{c}$. u. compared with the control $7.00 \pm 0.29 \mathrm{c}$. u. \\
\hline Activity of LDH & $7.00 \pm 0.51 \mathrm{c}$. u. compared with the control $6.00 \pm 0.32 \mathrm{c}$. u. \\
\hline The kidneys & $\begin{array}{l}\text { The structure of the nephron and its components are without visual } \\
\text { changes. Vacuoles are visible in the glomeruli of capillaries in } \\
\text { endotheliocytes }\end{array}$ \\
\hline Activi & $6.00 \pm 0.27 \mathrm{c}$. u. compared with the control $7.00 \pm 0.29 \mathrm{c}$. u. \\
\hline Activity of LDH & $6.00 \pm 0.35 \mathrm{c}$. u. compared with the control $6.00 \pm 0.32 \mathrm{c}$. u. \\
\hline
\end{tabular}

The results given in the table demonstrate that there is no damage to the target organs, there are signs of increased secretory activity of the gastric mucosa (goblet cells of the excretory ducts in the mucosa are sharply enlarged and rich in mucus). The activity of LDH in the tissues of the organs studied in intact animals is - (7.00 \pm 0.29$)$ conventional optical unit density, and
$\mathrm{LDH}$ activity is $-(6.00 \pm 0.32)$ conventional optical unit density. That is, the activity of redox enzymes in the tissues of the studied organs under the influence of the course with the use of sapropels without changes, as evidenced by the absence of significant changes compared with the control group ( $p>0.5)$.

Thus, in rats that received a course of six skin procedures with sapropels (every other day), there were no injuries to target organs signs of increased secretory activity of the gastric mucosa which were recorded the goblet cells of the excretory ducts in the mucosa are sharply enlarged and rich in mucus.

Stage II of the study consisted of an assessment of the acute toxicity of the sapropaste from the Prybych Lake. Primary goal in a toxicological study is to obtain information about the safety of a potential drug for health under short-term effects. These results are the basis for determining the toxicity class and establishing dosing regimens when conducting studies of subacute and chronic toxicity and provide primary information about the toxic effects of potential drugs.

In a study of acute toxicity study of the drug, integral indicator is the ratio of survival and mortality of animals that allow calculating the median lethal dose $\left(L D_{50}\right)$. If it is impossible to administer the drug in doses that cause the death of animals, the maximum dose of toxicity class IV is used to study acute toxicity, following the method of administration [22], [24], [25]. Therefore, if it is found that the test sample is non-toxic at a dose of $2810 \mathrm{mg} / \mathrm{kg}$ by cutaneous application, further studies may be considered inappropriate.

When determining the acute toxicity of the sapropel of Prybych Lake, the research results demonstrated the absence of animal death during the application of experimental samples (Table 3).

Table 3: Survival of rats in an experiment to study the acute toxicity of sapropaste with 1 time cutaneous application ( $n=10)$

\begin{tabular}{lll}
\hline Animal group & Dose, $\mathrm{mg} / \mathrm{kg}$ & Animals that died/total number of animals \\
\hline Sapropaste test sample & 2810 & $0 / 10$ \\
\hline
\end{tabular}

Thus, the $L_{50}$ of sapropaste is beyond the limits of the IV toxicity class $\left(\mathrm{LD}_{50}>2810 \mathrm{mg} / \mathrm{kg}\right)$, which allows them to be classified as practically non-toxic substances (V toxicity class) [24], [25].

A study to identify sensitizing and locally irritating properties is a mandatory requirement of the Pharmacological Committee of the Ministry of Health of Ukraine in the preclinical research of new drugs. As the study showed, 10 and 20 applications of the studied drugs did not change the general condition of the animals: They were mobile and active. Testing carried out after 10 applications showed the absence of manifestations of any irritating effect of sapropaste, as well as an allergic skin reaction in response to the final application of sapropaste (Table 4).

Therefore, by the methodological recommendations, the cutaneous application was 
Table 4: The study of the irritating and sensitizing effect of sapropaste

\begin{tabular}{|c|c|c|c|c|}
\hline \multirow[t]{3}{*}{ Groups of animals } & \multicolumn{4}{|l|}{ Duration of experiment, days } \\
\hline & \multicolumn{2}{|l|}{ After 10 applications } & \multicolumn{2}{|l|}{ After 20 applications } \\
\hline & $\begin{array}{l}\text { The difference in the thickness of } \\
\text { the skin fold, } \mathrm{mm}\end{array}$ & $\begin{array}{l}\text { The reaction of the } \\
\text { skin, points }\end{array}$ & $\begin{array}{l}\text { The difference in the } \\
\text { thickness of the skin fold, mm }\end{array}$ & $\begin{array}{l}\text { The reaction of the } \\
\text { skin, points }\end{array}$ \\
\hline \multicolumn{5}{|c|}{ Irritant effect (application on the right side of rats) } \\
\hline $1^{\text {st }}$ group & $0.05(0.0 \div 0.1)$ & $0(0 \div 0)$ & $0.25(0.2 \div 0.3)$ & $0(0 \div 0)$ \\
\hline $2^{\text {nd }}$ group & $0.05(-0.1 \div 0.3)$ & $0(0 \div 0)$ & $0.3(0.1 \div 0.4)^{*}$ & $0(0 \div 0)$ \\
\hline \multicolumn{5}{|c|}{ Sensitizing effect (application on the left side of rats) } \\
\hline $1^{\text {st }}$ group & $0.16(0.0 \div 0.2)$ & $0(0 \div 0)$ & $0.05(0.0 \div 0.1)$ & $0(0 \div 0)$ \\
\hline $2^{\text {nd }}$ group & $0.15(0.0 \div 0.3)$ & $0(0 \div 0)$ & $0.04(0.0 \div 0.1)$ & $0(0 \div 0)$ \\
\hline
\end{tabular}

continued up to 20 times [20], [21]. After applying 20 applications of sapropel on the right side, the irritating properties of sapropaste were not found. The application of the final skin application of the studied drugs to the left side did not cause hyperemia on the skin in any of the animals, which indicates the absence of sensitizing effect (Table 4).

\section{Conclusions}

1. After the toxicological and biological assessment, it was found that the 6-day course of cutaneous application of sapropel from Prybych Lake does not have a harmful or toxic effect on the functional state of the CNS of rats, increases EA: It contributes to the development of an excellent emotional (comfortable) state in the form of a significantly increased duration of grooming $(p<0.05)$ and stimulates individual autonomic reactions

2. The results of the study of structural and functional changes in target organs demonstrated the absence of toxic effects of sapropel mud solution on the liver, kidneys, heart, and stomach. There were signs of increased secretory activity of the gastric mucosa

3. It was experimentally established that sapropaste does not exhibit sensitizing and locally irritating properties and belongs to the class of practically non-toxic substances (toxicity Class V)

4. The results of these experimental studies indicate that the sapropel from the Prybych Lake and its processing products are not toxic, allergenic, or irritant, and can be used in balneology, medicine, and pharmacy.

\section{References}

1. Kala KJ, Prashob PK, Chandramohanakumar N. Humic substances as a potent biomaterials for therapeutic and drug delivery system-a review. Int J Appl Pharm. 2019;11(3):1-4.
2. Peña-Méndez EM, Havel J, Patočka J. Humic substancescompounds of still unknown structure: Applications in agriculture, industry, environment, and biomedicine. J Appl Biomed. 2005;3:13-24. https://doi.org/10.32725/jab.2005.002

3. Ozkan A, Sen HM, Sehitoglu I, Alacam H, Guven M, Aras AB, et al. Neuroprotective effect of humic acid on focal cerebral ischemia injury: An experimental study in rats. Inflammation. 2015;38(1):32-9. https://doi.org/10.1007/s10753-014-0005-0 PMid:25173888

4. Kodama H, Denso, Okazaki F, Ishida S. Protective effect of humus extract against Trypanosoma brucei infection in mice. J Vet Med Sci. 2008;70(11):1185-90. https://doi.org/10.1292/ jvms.70.1185

PMid:19057136

5. Vucskits AV, Hullár I, Bersényi A, Andrásofszky E, Kulcsár M, Szabó J. Effect of fulvic and humic acids on performance, immune response and thyroid function in rats. J Anim Physiol Anim Nutr (Berl). 2010;94(6):721-8. https://doi. org/10.1111/j.1439-0396.2010.01023.x

PMid:21073632

6. Krempaská K, Vaško L, Vašková J. Humic acids as therapeutic compounds in lead intoxication. Curr Clin Pharmacol. 2016;11(3):159-67. https://doi.org/10.2174/1574884711666160 813233225

PMid:27526696

7. Bolbatovski GN, Mazur NV, Pirogova LA. Innovative Technologies in the Use of Natural Therapeutic Mud. Medical News; 2014.

8. Espejo-Antúnez L, Cardero-Durán MA, Garrido-Ardila EM, Torres-Piles SB. Clinical effectiveness of mud pack therapy in knee osteoarthritis. Rheumatology (Oxford). 2013;52(4):659-68. https://doi.org/10.1093/rheumatology/kes322

PMid:23236190

9. Efendieva FM, Aliev AA, Balakisheva FK, Nabiev NN, Salmanov MM. The Transdermal Application of Dry Knoll Therapeutic Mud in the Practice of Non-spa Treatment. Physiotherapy Balneology and Rehabilitation; 2013.

10. Gushcha SG, Nasibullin BA, Plakida AL, Volyanskaya VS Physiological mechanisms of influence of table and treatment mineral waters based on the balgeneological measure magnesium oil on some systems of health organism in experiment. Int $\mathrm{J}$ Mol Biol Open Access. 2018;3(3):100-1. https://doi.org/10.15406/ijmboa.2018.03.00059

11. Badyal DK, Desai C. Animal use in pharmacology education and research: The changing scenario. Indian J Pharmacol. 2014;46(3):257-65. https://doi.org/10.4103/0253-7613.132153 PMid:24987170

12. Gudz NI, Kalynyuk TG, Bilous SB, Smetanina KI. Good Pharmacy Practices: A Workshop for Graduate Students. Ukraine: Nova Knyga; 2013. p. 368

13. Nikipelova OM, Solodova LB. A Guide to the Methods of Controlling Peloids and their Preparations. Part 1. Physico-chemical Research. Odesa, Ukraine: Ministry of Health of Ukraine, Research Institute of Medical Rehabilitation Therapy; 2008. p. 100.

14. Strus OY, Geyderikh OG, Silaeva LF. The Studies on Development of the Composition of Masks with the Sapropel 
Paste. News of Pharmacy; 2016. https://doi.org/10.24959/ nphj.16.2132

15. European Communities. Council Directive 86/609/EEC of 24 November 1986 on the Approximation of the Laws, Regulations and Administrative Provisions on the Member States Regarding the Protection of Vertebrate Animals Used for Experimental and Other Scientific Purposes. Brussels, Belgium: European Communities; 1986. p. 1-29. https://doi. org/10.5040/9781472559500.0009

16. National Research Council. Committee for the update of the guide for the care and use of laboratory animals. In: Guide for the Care and Use of Laboratory Animals. $8^{\text {th }}$ ed. Washington, DC: National Academies Press, US; 2011. https://doi. org/10.17226/25801

17. Walsh RN, Cummings RA. The open-field test: A critical review. Psychol Bull. 1976;83:482-504.

PMid: 17582919

18. Lojda Z, Grossrau R, Schiebler TN. Enzyme Histochemistry: A Laboratory Manual. New York: Springer-Verlag BerlinHeidelberg; 1979.

19. Ministry of Health of Ukraine. On Approval of the Recommendations of the Research Methods of Biological Effects of Natural Medical Resources and Preformed Medicines. Kyiv: Ministry of Health of Ukraine; 2009. Available from: http://www.old.moz.gov.ua/ua/portal/dn 20090928692. html. [Last accessed on 2009 Sep 28]. https://doi. org/10.31928/2305-3127-2018.4.3035

20. Stefanov OV. Preclinical Research of Medicinal Products. Kyiv: Medical Center Avicenna; 2001. p. 528.

21. Order of the Ministry of Healthcare. Procedure for Conducting Preclinical Study of Drugs and Examination of Materials for Preclinical Study of Drugs. No. 944. Available from: https://www. zakon.rada.gov.ua/laws/show/z005310. [Last accessed on 2009 Dec 14].

22. Tatem KS, Quinn JL, Phadke A, Yu Q, Gordish-Dressman H Nagaraju K. Behavioral and locomotor measurements using an open field activity monitoring system for skeletal muscle diseases. J Vis Exp. 2014;91:51785. https://doi.org/10.3791/51785 PMid:25286313

23. Gamma TV, Korenyuk II. Effects of bemitil and benzimidazole on behavior of rats in open-field test. Neurophysiology. 2006;38(1):75-80. https://doi.org/10.1007/ s11062-006-0028-8

24. Sidorov KK. On the Classification of Toxicity of Poisons with Parenteral Routes of Administration. Toxicology of New Industrial Chemicals. Moscow: USSR Academy of Medical Sciences; 1973. p. 47-57.

25. Berezovskaya IV. Classification of chemicals according to the parameters of acute toxicity with parenteral administration methods. Pharm Chem J. 2003;37(3):32-4 